\title{
PARTAI-PARTAI ISLAM DI INDONESIA \\ (Latar Belakang dan Dinamika Perjalanannya)
}

Oleh:Ikrar

\begin{abstract}
ABSTRAK
Tujuan pokok tulisan ini ialah melihat secara akurat realitas politik yang tercermin dalam tingkah laku politik partai-partai Islam pada periode orde lama hingga orde baru, suatu periode yang cukup penting dan genting hila ditempatkan dalam suatu perspektif sejarah perjuangan partai-partai Islam di Indonesia.

Ada 2 (dua) alasan penting dalam menelaah partai-partai Islam di Indonesia, yaitu:Pertama, sekalipun mayoritas rakyat Indonesia memeluk Islam secara serius atau sehaliknya, posisi politik Islam pada periode tersebut relatif lemah. Partai-partai Islam pada waktu itu merupakan kelompok politik minoritas dalam lembaga kenegaraan. Sebagai kelompok minoritas, mereka hanya melakukan peran penggerak dalam membericorak Islam pada perkembangan politik di Indonesia. Sebagai konsekwensi logis yang harus diterima dalam realitas sejarah politik. Hanya menyesuaikan diri dengan sistem dan tata politik yang baru dibawah satu komando. Kedua, alasan mengkaji masalah ini karena belum ada kajian khusus yang dilakukan dengan topik Islam dan relevansinya dengan partai-partai dalam wacana politik praktis selama ini. Kajian ini dilakukan selama periode orde lama sampai orde baru dengan titik tekan pada tingkah laku politik partai-partai Islam dan dinamika perkembangannya.
\end{abstract}

Jurnal Al-Syir'ah Vol. 1 No. 2 Juli-Desember 2003 


\section{PENDAHULUAN}

Pernyataan Filosofis Aristoteles seperti dikutip oleh Tobroni dan Syamsul tenting politik merupakan Master of science didasari oleh perttmbangan bahwa politik adalah realitas kehidupan manusia. Politik dalam konteks normatif merupakan bentuk asosiasi manusia dalam upaya mencapai kehaikan bersama (publik goad), menjadi bagian terpentmg dalam kehidupan. Sehingga dapat dikatakan. sejarah manusia berawal dart kegiatan vane bercorak politis.'

Dalam kerangka tersebut memerlukan struktur kehidupan yang disehut dengan polis atau negara. Dalam seiarahnya, kebutuhan manusia terhadap politik dalam bentuknya Yang kongkrit. tidak serta merta terbentuk menjadi stuktur kenegaraan dalam tatanan modem sepern saat ini.

Demikian halnya dengan umat Islam, ketika Indonesia memproklamirkan kemerdekaannya pada tanggal Agustus 1945, pada umumnva masvarakat Indonesia memperlihatkan sikap dan kecenderungan yang berbeda dari sehelumnva. Mereka tidak lagi sebagai orang yang pasif dan diam seperti zaman tempo dulu yaitu zaman penjajahan. NIereka pada umumnya memperlihatkan ciri-ciri sikap dan pandangan tertentu yang terbentuk olehmasa silam. Ciri dan pandangan tersebut, bersama-sama dengan persoalan antar suku, paling tidak akan memberi pengeruh ke arah mana kehidupan sosial politik akan berkembang selanj utnya. ${ }^{2}$

Pada masa inilah, ketika rasa nasionalisme medem Indonesia masih baru tumhuh. kata Islam merupakan kata pemersatu bagi bangsa Indonesia yang herhadapan bukan saja dengan bangsa Belanda melainkan juga dengan orang Cina. Perasaan bersatu seperti yang dijumpai pada kalangan Islam itu berkembang terus sungguh pun perbedaan suku serta tingkat loyalitas politik juga tampak.

Sungguhpun demikian, perpecahan antara umat Islam tidak dapat dihindariyang tercatat di tahun 1911-an. Kalangannasionalis yang netral agama (walaupun beragama Islam) menentang kepemimpinan mereka yang berorientasikan Islam. 
Demikian juga, golongan yang berusaha keras mengambil alih kepemimpinan Searikat Islam. Bib komunis umumnyaanti-Islam, golongan nasionalis yang netral agama ingin membatasi agama pada bidang perseorangan.'

Dalam situasi demikian, para pemimpin nasionalis Islam dengan gigih membentuk g,erakan Islamisasi secara massal melalui media pendidikan, sosial, kemanusiaan dan media dakwah lainnva ang ditangani oleh organisasiorganisasi Islam, misalnya Muhammadiyah, Nandatul Ulama, Persis, Partai Syarikat Islam dan sebagainya.

\section{LATAR BELAKANG BERDIRINYA PARTAI ISLAM}

\section{A. Pemikiran Pendirian Partai-partai Islam}

Partai Islam yang dimaksudkandalam tulisan ini adalah, suatu perkumpulan yang seasas, sehaluan dan setujuan. ${ }^{4}$ Dengan demikian, Partai Islam merupakan perkumpulan atau golongan yang menjadikan agama Islam sebagai asas partai.

Menjelang kemerdekaan Indonesia,para pemimpin Islam ketika itu tidaklah mementingkan berdirinya suatu negara yang berdasarkan Islam, tetapi yang terpenting adalah kemerdekaan Indonesia. Hai ini disebabkan karena pemikiran pemimpinpemimpin Islam pada saat itu didasarkan pada penduduk bangsa Indonesia yang sebagian besar beragamaIslam, yang menurutnya jumlah yang mayoritas agama Islam itu tentu akanmembentuk negara Indonesia yang berdasarkan Islam dan pemerintah yang beragama Islam. Dengan perkataan lain pemikiran pada saat itu adalah bahwa Indonesia setelah merdeka akan otomatis menjadi negara yang berdasarkan Islam.'

Hal lain yang menjadi kendala dalam pendirian negara Islam adalah dalam percaturan sejarah umat Islam, citacita untuk mendirikan negara Indonesia yang berdasarkan Islam bukan hal yang mudah untuk diwujudkan. Hal ini disebabkan, bukan saja tantangan yang berasal dari partai Islam sendiri, juga munculnya partai-partai nasional sekuler yang menjadi penghambat.

Hal ini dapat dilihat pada perkembangan sejarah partai-partai Islam sebelum dan sesudah kemerdekaan. Sarekat Islam yang merupakan parta Islam yang pertama di Jurnal Al-Syir'ah Vol. 1 No. 2 Juli-Desember 2003 
Indonesia telah memberikan sumbangan dalam kehidupan politikIndonesia pertama kali yang harus dilihat dari perjuangan organisasiSarekat Islam (SI), sebagai partainasional yang besar yang pertama dalam programnya tidak menyebut-nyebut negara Islam, yang dituntut adalah kemerdekaan Indonesia.' Serikat Islam (SI) didirikan alas dua alasan : (1). Kompetisi yang makin meningkat dalam perdagangan baik, terutama dengan golongan Cina sehubungan dengan berhasilnya revolusi Cina pada tahun 1911. (2). Adanya tekanan dari masyarakat Indonesia, yaitu dari Bengawan Solo. Sehingga lewat pertemuan Solo pada tangal 11 November 1912. 51) diubah menjadi Serikat.

Pada tahun 1918, pemimpin pusatSI kemasukan orang-orang yang berideologi komunis, seperti Semaun dan Darsono. Inritrasi pada tubuh SI akhirnya membuat perpecahan. Semaun dan Darsono yang kcluar dari SI kemudian membentuk partai Komunis 11india (Indonesia) pada tanggal 23 Mei 1920. pada mulanya memperoleh pengikut yang banyak. Tetapi karena seranganmereka kepada Islam membuat guru-guru agama dan haji serta para pengikut mereka di desa-desa meninggalkan gerakan Semaun dan Darsono itu."

Demikian pula Muhammadiyah, dibentuk pada tanggal 18 Nopember 1912 sebagai reaksi terhadap aktivitas misi-misi Kristen dalam mengadakan sekolah-sekolah mist .di Indonesia."' Muhammadiyah adalah organisasi sosial keagamaan yang ruang Iingkupnya sangat luas menyentuh seIuruh kehidupan masyarakat. Organisasi ini merupakan gerakan pcmbaharuan Islam di Indonesia yang bertujuan untuk meningkatkan kwalitas hidup umat."

Di bidang politik, Muhammadiyah memperlihatkan sikap yang beragam, suatu saat tampil sebagai pihak yangsangat kritis terhadap pemerintah, tetapipada saat yang lain tampil sebagai pendukung, bahkan ikut dalam pemerintahandan pada saat yang lain menjadi organisasi independen yang tidak memiliki hubungan apa-apa dengan parpol apapun.-

Nandlatul Ulama dibentukbulan Januari 1926, sering dikatakansebagai organisasi masa Islam tradisional,dengan ciri-ciri: (1). Menganut dan mengembangkan ajaran empat mazhah. (2).Metode pendidikan yang diterapkan melalui pesantren. (3). Pola hubungan struktural internal komunitas yan2 menoniolkan peran kyai pada strata atas dengan berbagai legitimasinva."

Menurut Harun Nasution. pembentukan Nandlatul Ulama (NU) tidakberbeda dengan organisasi Islam sebelumnya, yaitu bukan untuk memperjuangkan negara berdasarkan Islam. tetapi Jurnal Al-Syir'ah Vol. 1 No. 2 Juli-Desember 2003 
mempersatukan ulama-ulama Indonesia yang berada di luar Muliammadivali. 1)i dalam kolonialisme Belanda. organisasi ini berpendirian tidak turut campur dalam soal-soal politik,"

Demikianlah gambaran singkat sejarah pembentukan baik organisasi maupun partai Islam yang bereorak nasional dan pada umumnya pendiriannva ketika itu bukanlah ke arah pembentukan ide negara berdasarkan Islam.

\section{B. Partai-Partai Islam di Masa Kemerdekaan}

Berdirinva parta Islam pada masa merdeka perlu dilihat dari latar belakang perkembangan politik di Indonesia pada masa itu, seperti yang telah dikemukakan pada awal pembahasan ini, bahwa SI yang telah dimasuki oleh orang-orang yang berideologi komunis, dalam tuhuh organisasi ini juga telah menjadi perpecahanyang merupakan salah satu faktor penyebab lemahnya organisasi Islam.

Akibamya, sekalipun SI mampu bertahan, tetapi sejak tahun 1990-an pengaruhnya dalam perpolitikan Indonesia semakin kecil. Pada tahun 1933 Soekiman dipecat dari SI (pada saat itu sudah berubah menjadi PSII). Sehingga, mereka yang merasa kecewa kemudian mendirikanpartai barn. Pada tahun 1938 berdiri Partai Islam Indonesia (PII) yang didukung oleh Muhammadiyah, Persis, Thawalib dan bekas anggota Permi di Sumatera.'

Dapat disimpulkan, bahwa sejak dekade 1930-an SI bukan lagi satu-satunya partai politik Islam. Apalagi, pada bulan April 1927 dibentuk puta di Bandung Perserikatan Nasional Indonesia (PNI) di hawah pimpinan Ir. Soekarno. Partai ini bertujuan agar kemerdekaan Indonesia bersifat sekuler.

Munculnya partai sekuler ini memberi kesadaran pemimpin-pemimpin Islam dan alim ulama. bahwa kemerdekaan Indonesia kelak seeara tidak otomatis akan membentuk negara yang berdasarkan Islam. Terbentuknyaa PNI tahun 1927menandai semakin dommannya peran kelompok nasional sekuler dalam perpolitikan pada saat itu. Meskipun partai ini tidakberumur panjang karena dibubarkan olehBelanda pada tahun 1931. Ideologi nasionalisme diteruskan oleh berbagai partai politik yang lahir kemudian, seperti Partindo. PNI Baru dan Parindra.

Jurnal Al-Syir'ah Vol. 1 No. 2 Juli-Desember 2003 
Lemahnva peranan partai-partai Islam semakm jelas pada waktu permulaan kemerdekaan dihandingkan dengan kedudukan mereka yang netral agama, ini terlihat pada pembentukan BPUPKI.

BPUPKI yang memiliki arti pentimg karena untuk pertama kalinyadalam sejarah, para pemimpin Indonesia berkumpul dalam satu wadah, dengan membicarakan persiapan kemerdekaan bangsa, beserta perlengkapannya seperti, dasar negara, kabinet dan parlemen. ${ }^{17}$ Komposisi keanggotaan BPUPKI yang atas 68 orang dari Jepang, 15 orang dari golongan Islam, selebihnya dari golongan nasional sekuler dari priyayi Jawa yang diketuai oleh Wiedyoningrat."

Selanjutnya, dalam sidang-sidang PPKI (Panitia Persiapan Kemerdckaan Indonesia), golongan nasionalis Islam menghendaki negara Islam yang memakai Islam sebagai undangundangnya. Sedang golongan nasionalis sekuler menghendaki negara Pancasila. Penyelesaian pertentangan ini kemudian diserahkan kepada satu panitia kecil yang terdiri atas 9 orang anggota. Golongan nasionalis sekuler diwakili oleh Ir. Soekarno, M. Hatta, M. Yantin, A. Soebarji dan A. Maramis,sedangkan wakil dari golongan nasionalis Islam adalah H. Agussalim, KH. Wahid Hasyim, A. Kahar Muzakkir dan Abikusno. ${ }^{19}$

Penyelesaian akhirnya diperoleh dalam bentuk Piagam Jakarta. Pancasila diterima sebagai dasar negara yang akan dibentuk, tetapi ke dalamnya ditamhahkan suatu ketentuan mengenai umat Islam, sehingga sila pertamanya berbunyi : Kepercayaan Pada Tuhan Yang Maha Esa dengan kewajiban kepada umat Islam menjalankan Syari'atnya. Selanjutnya disepakati untuk menjadikan Piagam Jakarta sebagai Preambule UUD. Tetapi ketika Preambule itu dibacakan, ketentuan mengenai umat Islam tersebut ditinggalkan. Sementara protes dari golongan nasionalis Islam terhadap penghapusan klausal tidak kedengaran..$^{\circ}$

Beberapa cendekiawan muslim beranggapan bahwa diterimanya ideologinegara Pancasila dan dihapusnya tujuh patch kata dalam Piagam Jakarta merupakan kekalahan politik.

Jurnal Al-Syir'ah Vol. 1 No. 2 Juli-Desember 2003 


\section{Berdirinya Masyumi}

Kekalahan politik yang dialami umat Islam, menyebabkan mereka merasasenasib. Sehingga, dikeluarkannya maklumat Pemerintah Nomor $\mathrm{X}$ tanggal 3 Oktober 1945, tentang anjuran membentuk partai politik. Kaum nasionalis Islam mulai memikirkan suatu partai politik yang dapat menjadi payung bagi semua organisasi Islam pada masa itu.22 Meskipun kalangan nasionalis Islam menganggap pengumuman itu tidak tepat waktu,tetapi pun mereka berpendapat hahwa dengan berdirinya partai-partai berhagai aliran dalam masyarakat mendapat penyaluran. Itu sebab, umat Islam merasa berkewajiban mengorganisasikan kekuatan dalam suatu wadah politik agar dapat melaksanakan tugasnya dibidang.

Juga kesadaran umat Islam akan kedudukan yang tidakmenguntungkan pada permulaan kemerdekaan dibanding dengan golongan nasional sekuler. Hal ini mcrupakan kemerdekaan umat Islam yang juga lemah dalam badan penyelidik dan dalam Panitia Kemerdekaan Indonesia. Faktor lain adalah berdimya PNI pada hulan Agustus 1945 yang menurut pimpinan negara mcrupakan satu-satunya partai di negara Baru itu. Sungguhpun partai ini dikatakan tidak mempunyai hubungan dengan PNI yang dipimpin oleh Ir. Soekarno pada tahun 1920-an, rakyat awam menyangka sebaliknya, karena dukungan yang diberikan oleh Soekarno dan Hatta. Tetapi, dengan munculnya yaitu PNI yang bukan merupakan partai negara. Tetapi, masih tetap dianggap sebagai lanjutan dari PNIlama sebelummenguntungkan pada permulaan kemerdekaan dibanding dengan golongan nasional sekuler. Hal ini merupakan kemerdekaan umat Islam yang juga lemah dalam badan penyelidik dan dalam Panitia Kemerdekaan Indonesia. Faktor lain adalab berdimya PNI pada hulan Agustus 1945 yang menurut pimpinan negara mcrupakan satu-satunya partai di negara Baru itu. Sungguhpun partai ini dikatakan tidak mempunyai hubungan dengan PNI yang dipimpin oleh Ir. Soekarno pada tahun 1920-an, rakyat awam menyangka sebaliknya, karena dukungan yang diberikan oleh Soekarno dan Hatta. Tetapi, dengan munculnya yaitu PNI yang bukan merupakan partai negara. Tetapi, masih tetap dianggap sebagai lanjutan dari PNI lama sebelum perang. Beberapa waktu kemudian setelah munculnya 
partai-partai lain citra PN1 berubah. Kalangan nasionalis sekuler mendapat ancaman dari kalangan Islam."

Maka, pada tanggal 7 dan S Nopember 1945. diadakanlah Muktamar Islam Indonesia di Jogjakarta yang dihadiri oleh hampir semua tokoh berhagai organisasi Islam dun masa sebelum perang serta pada masa pendudukan Jepang. Kongres kemudian memutuskan untuk mendirikan Majelis Syuro Pusat bagi umat Islam di Indonesia. Dalam Muktamar tersebut diputuskan pula bahwa Masyumi adalah salu-satunvu partai politik umat Islam Indonesia."-

Masyumi terdin alas dua macam anggota yaitu: perseorangan dan organisasi. Organisasi pertama yang masuk Masyumi adalah Muhamadiyah, Nandlatul Ulama. Perserikatan Umat Islam, dan Persatuan UmatOrganisasi-organisasi lain di Jawa seperti Persatuan Islam (Bandung) tahun 1945 dan al-Irsyad (Jakarta) bergabung tahun 1950-an.' Dan selanjumya organisasi di daerah-daerah bergabung dengan Masyumi dan menjadikan diri sebagai cabang. Sehingga dalam waktu setahun sejak didirikan, Masyumi sudah mengungguli PNI dan menjadi parpol terbesar di Indonesia pada masa itu.

Perjuangan Masyumi di kancah politik antara tahun 1945-1949 dengan segala potensi kekuatan dikerahkan untuk mempertahankan kemerdekaan. Setelah Belanda dengan membonceng pihak sekutu datang kembali untuk menjajah Indonesia. Mereka menolak segala perundingan dengan Belanda karena dipandang menodai perjuangan. ${ }^{-6}$

\section{PARTAI-PARTAI ISLAM DIPENTAS NASIONAL}

\section{A. Partai-partai Islam Setelah Kemerdekaan}

Akibat turun naiknya kabinet dalam masa revolusi peranan Masyumi beragam. Kabinet presidentil yang dibentuk bulan Agustus 1945. Sebulan kemudian diganti dengan sistem kabinet dengan sistem parlementer dengan Kabinet Syahrir 1. Dalam Kabinet Syahrir I, II, III antara 1945-1947. Masyumi bertindak sebagai oposisi kendatipun beberapa orang anggotanya alas nama pribadi menjadi anggota kabinet tersebut. Kabinet Syahrir III jatuh karena dampak perjanjian Linggariati yang ditandatangani PM Syahrir.- Selanjutnya Kabinet Amir Syarifuddin 
I. dan Masyumi partai oposisi. Tetapi, persatuan umat Islam mulai retak karena dengan lihai Amir Syarifuddin membujuk unsur PSII untuk bergabung dalam kabinetnya. Tanpa keikutsertaan golongan Islam, Amir berkevakinan kabinetnya kurang mendapatkan legitimasi. Karena tidak berhasil melakukan kesepakatan dengan Masyumi tentang komposisi cabinet, ia membujuk PSII untuk ikut serta. Itulah pukulan begat bagi Masyumi ketika PSII menarik diri dari Masyumi deng.an berdiri sendiri sebagai partai

Dalam Kabinet Amir Syarifuddin II, Masyumi bersedia ikut serta dengan maksud mempengaruhi PM. Amir Syarifuddin dalam perundang-undangannla dengan pihak Belanda. ${ }^{-9}$ Namun usaha ini gagal dengan disepakatinya perjanjian Renville, setelah timbulnya perpecahan internal PM. Mr. Amir Syarifuddin menverahkan mandatnya kepada Presiden. Kemudian terbentuk Kabinet Muhammad Hatta yang merupakan ekstra kabinet dan paling lama memerintah dalam masa revolusi tersebut. Dalam kabinet ini dudukempat orange dari Masyumi dan empatorang dari PNI. Kabinet ini harus menengani empat hal krusial yaitu : 1). Gerakan Darul Islam, 2) Konsekwensi Renville. 3) Penyerahan mereka sampai penyerahan kedaulatan Belanda lewat KMB. Dan 4) Penanganan Pemberontakan Musso-PKI di Madiun 1948. ${ }^{31)}$

Dalam masa itu pulalah sejarahmencatat peranan Masyumi dalam penyelesaian revolusi. Ketika berlangsung Agresi Belnda II, banyak oerjabat negara ditangkap termasuk Soekarno, Muh. Hatta, M. Natsir. Atas inisiatif sendiri Mr. Syarifuddin Prawiranegara membentuk pemerintah darurat di Sumatra Tengah. Berkat pemerintah darurat itulah kevakuman kekuasaan dapat terhindarkan karena Belanda tidak dapat mengklaim kepada dunia internasional bahwa Indonesia telah bubar. ${ }^{31}$

Tetapi, dalam perjalanan sejarah Masyumi mengalami pasang surut, sebagai wadah politik tunggal bagi umat Islam Indonesia, para pemimpin Islam bertekad untuk mengisi dan mempertahankan negara Indonesia yang Baru dipertahankan sertamemperjuangkan nilai-nilui Islam sebagai dasar dalam kehidupan kenegaraan, namun tekad itu mendapat ganjalan. ${ }^{32}$

Ada beberapa hal yang menyebabkan mengapa NU keluar dari Masyumi, pertaina, NU tidak menyetujui perubahan rumusan dalam Majelis Syuro dalam AD/ART Masyumi. NU menganggap bahwa dengan menjadikan Majelis Syuro sekedar bahan penasehat, organisasi ini tidak memberikan tempat yang layak bagi ulama. Sementara Majelis Syuro mayoritas berasal dari NU, 
dan perubahan-perubahan tersebut diotaki oleh tokoh-tokoh Masyumi dan Muhammadiyah. ${ }^{33}$ Kedua, yang merupakan sebab langsung, berkaitan dengan pembentukan kabinet.

Pada saat Kabinet Sukiman menyerahkan mandatnya kepada pemerintah, ditunjuki ketua formatur Siddik Djojokusukanto (PN1) dan Mid-Formatur Prawoto Mangkusasmito (Masyumi). Pada tahun1952 Rats Aam Majelis Syuro NU, KH. Abdul Wahab Hasbullan, agar kursi menteri agama di dalam kabinet yang akan dibentuk diduduki oleh seorang NU. Namur sebagai Mid-Formatur, Prawoto menganggap hal ini bukan wewenangnya, setelah dilakukan beberapa kali perundingan akhirnya keinginan NU tidak terpenuhi ${ }^{34}$

Dalam Konfrensi NU se-Jawa dan Madura di Jegalan pada tanggal 5-6 April 1952, diputuskan NU keluar dari masyumi.

Demikianlah, partai-partai Islam menurut Deliar Noer, dalam masa revolusi perhatian lebih ditujukan pada usaha mempertahankan kemerdekaan, tetapidalam masamasa setelah penyerahan kedaulatan tampaknya usaha diarahkan pada usaha mendapatkan tempat, dan kalau munakin tempat yang menentukan dalam kabinet. Dan, ini berlaku bagi semua partai Islam. ${ }^{36}$

\section{B. Islam dan Perpolitikan Orde Baru}

Keluarnya Surat Perintah 11 Malan 1966 merupakan titik awal lahirnya Orde baru. Pada masa orde baru ini, BU memperlihtkan dinamika sosial politik yang agak berlainan, dengan masa-masa sebelumnya. Dalam Pemilu 1974, NU berhasil mendapatkan posisi kedua dibawah Golkar clan diatas Parmusi (nama lain Masyumi). Berdasarkan kebijakan rezim orde ham, yaitu mclakukan deparpolisasi dalam rangka pembentukan sistem kepartaian yang hegemonik setelah Pernik' 1971 terjadi fusi partai. NUbersama PS11, Peril dan Parmusi (yang kemudian berubah nama menjadi Muslim Indonesia). Pada tanggal 5 Januarimelebur dakam Partai Persatuan 
Pembangunan (PPP).' Dan pada tanggal 10 Januari 1973 PNI, Partai Katolik, Parkindo. IPKI dan Murba berlusi dalam Partai Demokrasi Indonesia (PDI)."

PPP sejak didirikan secara ielas mengatasnamakan sebagai partai Islam dengan berazaskan Islam. Dalam perjuangannya PPP berhasil menggolkan pendidikan agama sebagai pendidikan agama disemua tingkat pendidikan ketika DPR mengadakan sidang pada tahun 1973, dan pada tahun yang sama. PPP berhasil memperjuangkan 1.ndangundang Perkawman yang men‘cerminkan aturan-aturan legalitas. Tetapi, disisi lain PPP menampakkan ketegarannya ketika berlangsung siding Umum MPR 1978, pada saat masalah kepercayaan terhadap Tuhan Yang Maha Esa diangkat kembali sebagai agenda persidangan.

Beberapa saat kemudian PPP harus merekonstruksi dasar ideology setelah berlangsung azas tunggal. Perubahan mendasar yang berlangsung dalam tubuh PPP adalah dilepaskannya Islam sebagai azas Partai. yang kemudian disusul langkah lainnya berupa pergantian Lambang Partai dart Kabah menjadi gambar Bintang. ${ }^{\circ}$

Keadaan tersebut di atas, sungguhdi luar dugaan para politisi Islam, saat PPP mulai dicanangkan terhadap suatu harapan partai ini akan memperoleh simpati umat Islam. Hal tersebut sima ketika umat Islam mengalami trauma politik yang berkepanjangan. Dart tiga Pemilu (1977, 1982, 1987) PPP tidak mengalami perkembangan yang menegembirakan. ${ }^{41}$

Faktor lain yang dialami oleh PPP adalah bervariasinya afiliasi politik kyaiterutama setelah dikeluarkannya UU. No. 3 tahun 1985 tentang partai politik dan Golkar. Apalagi pada Muktamar yang ke 27 di Situbondo, NU yang selama ini menjadi pendukung utama dari PPP menvatakan keluar dari PPP. ${ }^{4-}$

Kondisi ini semakin melemahkan posisi PPP, ini terlihat pada Pemilu 1992 misalnya, tidak sedikit pondok pesantren vang kvainva menyatakan dukungan atau diealonkan oleh oNanisasi politik selain PPP. seperti Golkar maupun PD1.

Kenyataan di atas, menunjukkan bahkan politik orde baru dengan menjadikan partai-partai Islam yang pada mulanya nrtsih berserahkan dalam berbagai segmen. telah Jurnal Al-Syir'ah Vol. 1 No. 2 Juli-Desember 2003 
membawa implikasi di luar apa yang menjadi harapan umat Islam. Dengan pengelompokan tersebut dengan sasaran depolitisasi Islam mudah digarap dan lebih clektit karena hanva berhadapan dengan saw partai. Dan bagi PPP, dengan hilngnya azas ke-Islam-an, herarti secara formal PPP telahmenjadi partai terbuka bags siapa saja. Dengan demikian, sejak penerimaan azas tunggal tersebut PPP bukan lagi partai politik Islam. Ini berarti pula habak akhir sejarah tahun 1997, merupakan habak terakhir bagi orde baru sebae.at akhir kruis ekonomi yang melanda bangsa Indonesia yang sekaligus krisis terhadap pemimpin dan Para elit politik membicarakan reformasi yang dimotori Mahasiswa kemudian bermuara pada runtuhnya baiwunan orde baru yang dulu begau kokoh, akhullya berakhir. Keadaan ini dttandal dengan lenngsernya Soeharto sebagai Presiden dan penguasa Orde Baru selama 32 tahun, pada tam/gal 21 Mci 1998 setelah digelar sidang istimewa.

Pada tan2gal 7 Juni 1999 diadakan pemilihan umum. Pemilu kali ini diikuti sekitar 48 partai, 11 diantaranya adalah partai herazaskan Islam di Indonesia,tetapi nampaknya peran yang dimainkan hingga saat ini belum menunjukkan hasil yang diharapkan oleh umat Islam.

\section{KES I M P U L A N}

Dari beberapa pemikiran tersebut di atas, dapat disimpulkan hal-hal sebagai berikut;

1. Berdirinya partai-partai Islam sebelum kemerdekaan pada prinsipnya bertujuan untuk mencapai kemerdekaan sekaligus mempertahankannya, bukan bertujuan untuk mendirikan negara yang berdasarkan, Islam.

2. Partai-partai Islam sebelum menjalankan peran politiknya banyak mendapat hambatan disebabkan karena faktor internal, juga kekuatan politik dari luar, seperti partai-partai nasional sekuler.

3. Partai-partai Islam dalam hal ini PPP pada masa Orde Baru, ketika harus merekonstruksi dasar ideologinya setelah diberlakukan azas tunggal partai secara formal PPP menjadipartai terbuka bagi siapa saja dan bukan lagi partai politik Islam. 


\section{CATATAN KAKI :}

1. Thobroni, et.al., IslamPluralisme Budaya dan Politik, (Cet. I: Jogyakarta: SINUS, 1994), h. 37.

2. Deliar Noer, Partin Islam di Pen/as Nasional, (Cet. II; Bandung: t. p, 2000), h. 1.

3. Ibid. h. 5-6.

4. WJS. Poerwadarninta, Kamus UmumBahasa Indonesia, (Jakarta: Balai Pustaka, 1982), h. 712.

5. Harun Nasution, Islam Rasional, (Cet. I; Bandung: Mizan, 1995), 11. 232-233

6. A. Azis 'Lm, Islam dun Ntwara Dalam Polit1k Orb Baru, (Cet. I: Jakarta: Gema lnsani Press, 1996), h, 141.

7. SI adalah lanjutan dari Sarckat Dagang Islam (SDI) yang pada tanggal 10 September 1912 diuhah menjadi partai poliiik. Pada tahun 1916, SI mempunyai anggota yang berjumlah 800.000 orang (sebagai perbandingan Budi Utomo 1912, mempunyai anggota 10,000 dan Indische Partal 191.

8. A. Azis Thaba, op.cit., h. 141-142

9. Harun Nasution, op. cit., h. 234.

10. Ibid., h. 233,

11. A. Azis Thaba, op. cit., h. 214.

12. Ibid.

13. Lihat, La Ode Ida, Ulumul Qur'an, Nomor V, Vol. VI, 1996.

14. Harun Nasution, op. cit., h.234.

15. Tokoh-tokoh P1l yang terkenal adalah Dr. Sukiman Wirjosandjoyo. Muhammad dan Abd. Kahar Muzakkar, Ibid, lihat A. Azis Thaba, op. cit., h. 143 